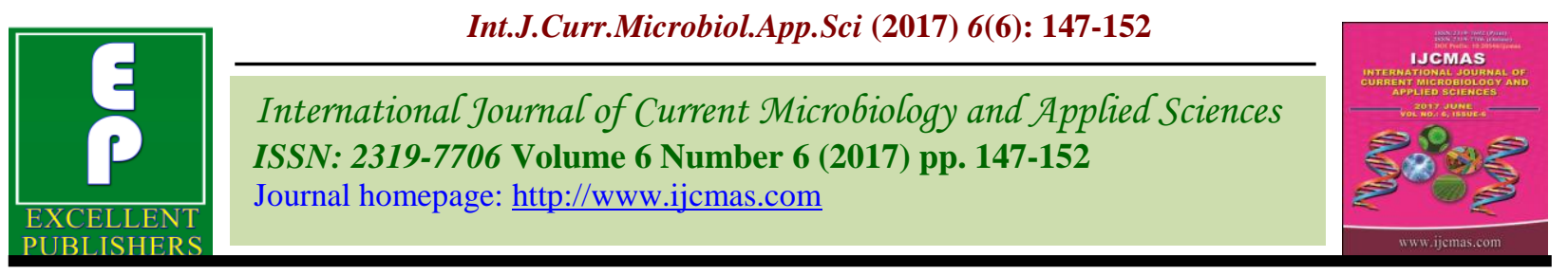

Original Research Article

https://doi.org/10.20546/ijcmas.2017.606.017

\title{
A Report on the Hepatopancreatic Microsporidiosis Caused by Enterocytozoon hepatopenaei (EHP) in Penaeus vannamei (Pacific White Shrimp) Farms in Thiruvallur District, Tamilnadu, India
}

\author{
M. Giridharan and A. Uma*
}

State Referral Laboratory for Fish Disease Diagnosis and Aquatic animal Health, Fisheries Research and Extension Centre, Tamilnadu Fisheries University, Madhavaram milk colony, Chennai - 600051, Tamil Nadu, India

*Corresponding author

\section{A B S T R A C T}

Keywords

Enterocytozoon hepatopenaei, Hepatopancreatic microsporidiosis, White fecal syndrome (WFS)

\section{Article Info}

Accepted: 04 May 2017 Available Online: 10 June 2017
Disease incidence is the most impeding factor in the development of shrimp aquaculture industry. Most of the disease incidence in shrimp aquaculture is attributed to viral pathogens. But more recently Enterocytozoon hepatopenaei (EHP), a microsporidian parasite, has emerged as a serious pathogen reported to be associated with white faecal syndrome (WFS) and retarded growth which is referred as hepatopancreatic microsporidiosis in cultured pacific white leg shrimp (P. vanammei) in many of the shrimp growing countries of Asia. In the present study, it is reported that the prevalence hepatopancreatic microsporidiosis in the $P$. vannamei shrimp farms in Thiruvallur district. A preliminary study was conducted for screening EHP with a total number of 54 samples comprising of shrimp's hepatopancreas, post larvae, faecal matter and soil by a nested polymerase chain reaction assay. The results showed that 10 samples were positive for EHP either in the first step or in the second (nested) step PCR with the prevalence of $18.51 \%$. This report alerts the shrimp farmers to undertake suitable management measures to prevent the spread of hepatopancreatic microsporidiosis and to avoid the disease in subsequent culture operations to improve the production and sustainability of shrimp culture.

\section{Introduction}

The shrimp aquaculture industry in India has witnessed massive improvement in production since the large scale introduction of the exotic species Penaeus vanammei (pacific white leg shrimp) in the year 2009 after which $P$. vanammei has totally dominated the Indian shrimp aquaculture sector over the indigenous black tiger shrimp (Penaeus monodon) as there is availability of specific pathogen free (SPF) and specific pathogen resistant (SPR) shrimp seeds. During 2014-15, shrimp aquaculture has shown a tremendous growth and achieved highest production of about 4, 34,558 metric tonnes (MPEDA, 2015).

Disease incidence is the most impeding factor in the development of shrimp aquaculture 
industry. Most of the disease incidence in shrimp aquaculture is attributed to viral pathogens. But more recently, incidence of EHP associated 'white faecal syndrome' (WFS) has caused severe growth retardation in cultured shrimp. WFS is characterized by the presence of white fecal strings in the affected ponds. EHP is confined to the tubular cells of hepatopancreas (HP) in the shrimp there by leading to reduced growth resulting in a condition called as hepatopancreatic microsporidiosis (Thitamadee et al., 2016). Production losses in shrimp culture due to EHP have been reported to be increasing over the last two years as effective control measures are not available. The first incidence of microsporidiosis in tiger shrimp was reported in Thailand by Anderson et al., (1989). Hudson et al., (2001) reported the incidence of microsporidian infection associated with mortalities in $\mathrm{P}$. japonicus from Australia. Chayaburakul et al., (2004) reported an undesignated microsporidian associated with monodon slow growth syndrome (MSGS) in Thailand. Tourtip et al., (2009) was the first to characterize EHP as a new microsporidian under the genus Enterocytozoon and a primer was designed based on the 18ssu rRNA of EHP. Molecular assays like nested PCR (Tangprasittipap et al., 2013; Jaroenlak et al., 2016), LAMP assay (Suebsing et al., 2013) and real time PCR assay (Liu et al., 2014) has been developed for detecting EHP. Rajendran et al., (2016) have reported the incidence of EHP in India. In the present study, prevalence of EHP was studied by PCR in the $P$. vannamei samples collected from the shrimp farms in and around Thiruvallur district.

\section{Materials and Methods}

\section{Sample collection}

Samples of post larvae, juveniles, faeces of $P$. vanammei and soil samples from $P$. vanammei culture ponds were collected from the shrimp farms located in Thiruvallur district of North Tamil Nadu. The shrimp and faecal samples were either fixed using $70 \%$ ethyl alcohol or transported under live conditions to the laboratory for analysis. Soil samples were transported to the lab in the moist condition to the lab for analysis.

\section{DNA extraction}

The genomic DNA was extracted from the hepatopancreas of juveniles, fecal strings and soil samples. In case of post larvae the whole larvae was pooled and DNA was extracted using a commercial DNA extraction kit (Qiagen, Germany) following the manufacturer's protocol. The extracted DNA was then suspended in $50 \mu 1$ of nuclease free water. The extracted DNA was quantified in a biophotometer (Eppendorf, Germany).

\section{PCR analysis}

PCR screening of EHP was carried out following a primers and protocol of a nested PCR assay that specifically targets sporewall protein coding gene (Jaroenlak et al.,2016). The PCR amplification was carried out in a thermal cycler (Biorad T100 Thermal cycler, USA) in a total volume of $25 \mu \mathrm{l}$ reaction mixture containing $2 \mathrm{X}$ mastermix RED (Ampliqon, Denmark) (Tris- $\mathrm{HCl}$ pH 8.5, $\left(\mathrm{NH}_{4}\right)_{2} \mathrm{SO}_{4}, 3 \mathrm{mM} \mathrm{MgCl} 2,0.2 \%$ Tween 20®, $0.4 \mathrm{mM}$ dNTPs, 0.2 units/ $\mu \mathrm{l}$ AmpliqonTaq DNA polymerase), $1.0 \mu \mathrm{l}(10 \mathrm{pmol})$ of forward (SPW-1F) and reverse primer (SPW2F) each, $1.0 \mu \mathrm{l}(50 \mathrm{ng})$ of sample DNA. The PCR cycling conditions followed was initial denaturation at $95^{\circ} \mathrm{C}$ for 5 min followed by 35 cycles of denaturation at $94^{\circ} \mathrm{C}$ for $20 \mathrm{sec}$, annealing of primers at $58^{\circ} \mathrm{C}$ for $20 \mathrm{sec}$ and extension at $72^{\circ} \mathrm{C}$ for $45 \mathrm{sec}$ with a final extension at $72^{\circ} \mathrm{C}$ for $5 \mathrm{~min}$. The nested PCR reaction was carried out similar to the first step PCR except for the nested primers and 
$1.0 \mu \mathrm{l}$ of the first step product as the template. The cycling conditions were set at initial denaturation at $95^{\circ} \mathrm{C}$ for $5 \mathrm{~min}$ followed by 20 cycles of denaturation at $95^{\circ} \mathrm{C}$ for $30 \mathrm{sec}$, annealing at $64^{\circ} \mathrm{C}$ for $30 \mathrm{sec}$ and extension at $68^{\circ} \mathrm{C}$ for $20 \mathrm{sec}$ with final extension at $68^{\circ} \mathrm{C}$ for $5 \mathrm{~min}$. An aliquot of PCR product was separated in $1.5 \%$ agarose gel containing 0.2 $\mu \mathrm{g} / \mathrm{ml}$ ethidium bromide alongside $2 \mu \mathrm{l} 100 \mathrm{bp}$ DNA ladder (GeneDirex) and the amplified DNA was visualised under UV illumination using a gel documentation system (Biorad, USA). The PCR product from the first step PCR was purified and sequenced with a commercial sequencing service (Eurofins, Bengaluru, India).

\section{Results and Discussion}

In a total of 54 samples of $P$. vanammei screened by PCR, one sample (hepatopancreas) was positive for the first step resulting in the amplification of $514 \mathrm{bp}$ product which reveals that the sample is heavily infected (Figure 1). However in the nested PCR, ten samples were found to be positive showing specific amplification at the $148 \mathrm{bp}$ fragment. The overall prevalence of hepatopancreatic microsporidiosis caused by Enterocytozoon hepatopenaei in the Penaeus vanammei farms located at Thiruvallur district was estimated to be around $18.51 \%$. The sample-wise prevalence percentage is presented in table 1 .

The prevalence of hepatopancreatic microsporidiosis associated with EHP infection has been reported in various countries like Malaysia, Australia, Thailand, Vietnam and China undertaking shrimp farming operations (Anderson et al., 1989; Hudson et al., 2001; Chayaburakul et al., 2004; Ha et al., 2010 and Liu et al., 2014). Thus EHP might be an endemic pathogen in the Australasian region (Thitamadee et al., 2016). In India white faeces and reduced growth associated with EHP infestation has caused severe production losses to the shrimp farmers and the first report on prevalence of EHP causing hepatopancreatic microsporidiosis in India was reported in 2016 (Rajendran et al., 2016). So far, molecular diagnosis of EHP was developed based on the primers that target the SSU rRNA genome of the parasite (Tourtip et al., 2009; Tangprasittipap et al., 2013; Liu et al., 2014; Tang et al., 2015). But recently, it has been reported that the primers targeting the SSU rRNA of EHP has cross reactivity with closely related microsporidians (Jaroenlak et al., 2016).

Table.1 Prevalence of hepatopancreatic microsporidiosis caused by Enterocytozoon hepatopenaei in Penaeus vanammei farms at Thiruvallur district

\begin{tabular}{|c|c|c|c|c|c|c|c|}
\hline \multirow[t]{3}{*}{ S. No. } & \multirow[t]{3}{*}{ Sample } & \multirow{3}{*}{$\begin{array}{c}\text { No of } \\
\text { samples } \\
\text { screened }\end{array}$} & \multicolumn{4}{|c|}{ PCR Results } & \multirow{3}{*}{$\begin{array}{c}\text { Prevalence } \\
(\%)\end{array}$} \\
\hline & & & \multicolumn{3}{|c|}{ Positive } & Negative & \\
\hline & & & I step & $\begin{array}{c}\text { Nested } \\
\text { step }\end{array}$ & Total & & \\
\hline 1 & Post larvae & 12 & 0 & 0 & 0 & 12 & 0 \\
\hline 2 & HP & 34 & 1 & 6 & 7 & 27 & 20.58 \\
\hline 3 & Faeces & 4 & 0 & 3 & 3 & 1 & 75.0 \\
\hline 4 & Soil & 4 & 0 & 0 & 0 & 4 & 0 \\
\hline 5 & Total & 54 & 1 & 9 & 10 & 44 & 18.51 \\
\hline
\end{tabular}


Figure.1 PCR amplification of spore wall protein gene of Enterocytozoon hepatopenaei

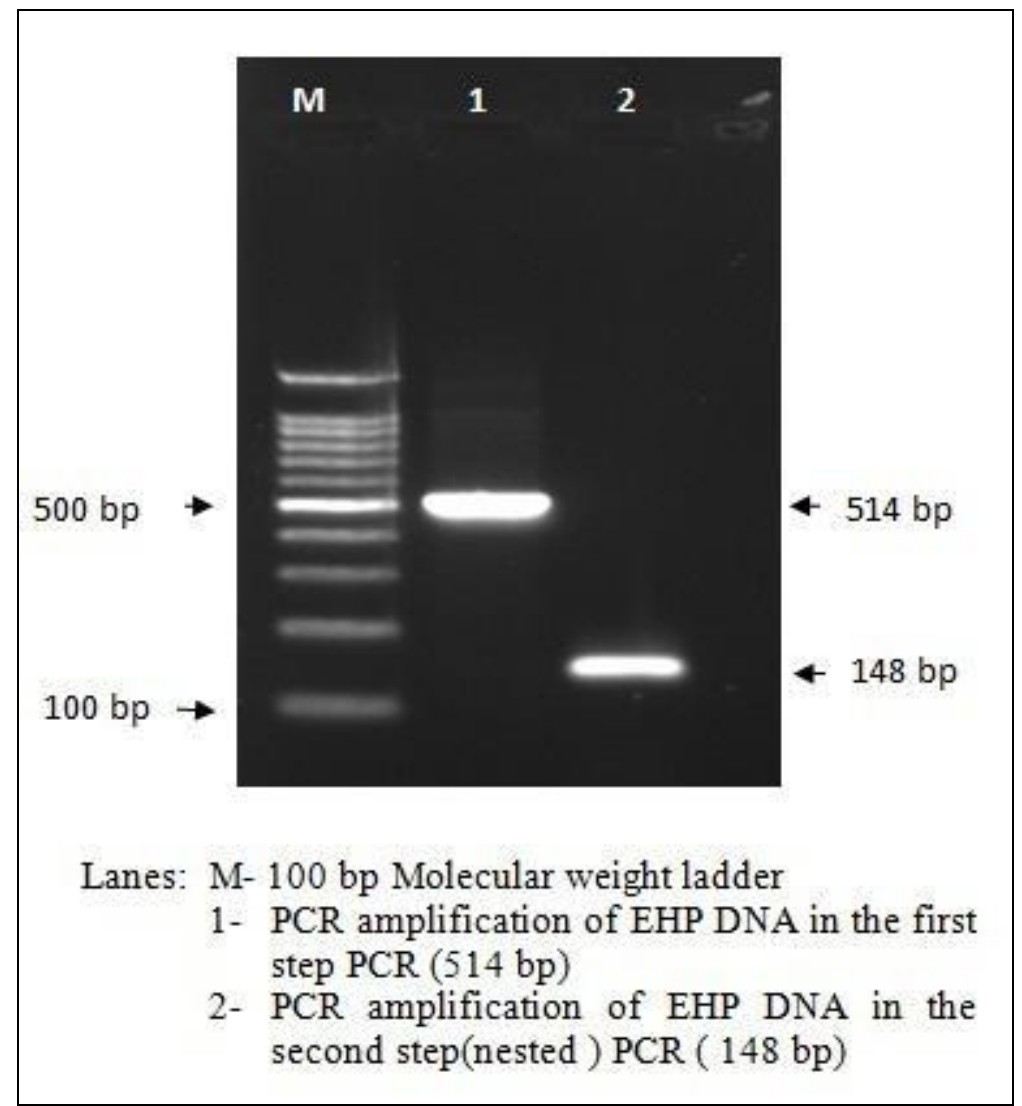

In the present study, the primers reported by Jaroenlak et al., (2016) has been used to screen the collected samples as it specifically targets the sporewall coding gene present in EHP. The prevalence of hepatopancreatic microsporidiasis recorded in the present study was $18.51 \%$ (10/54). The prevalence (\%) was observed to vary with the nature of sample used for screening of EHP in our study. The prevalence rate of EHP in post larvae was nil in this study which was in accordance with the findings of Rajendran et al., (2016) as post larvae are mostly specific pathogen free. In case of hepatopancreas samples from juveniles, the prevalence rate was moderately low $(20.58 \%)$. But in the earlier studies conducted by Rajendran et al., (2016) and Biju et al., (2016) the prevalence was high at a rate of $63.5 \%$ and $69 \%$ respectively. As reported by Thitamadee et al., (2016) E. hepatopenaei causing hepatopancreatic microsporidiosis is confined to tubule epithelial cells of the hepatopancreas. In this study, the fecal samples showed high prevalence of EHP at a rate of $75.0 \%$ and similar observations has also been made by Sriurairatana et al., (2014) under light microscopy. While screening soil samples the results were negative for EHP as probably the spores might have transmitted from soil to the host (Sritunyalucksana et al., 2014). Hepatopancreatic microsporidiosis does not cause any mortality but it is seriously associated with growth retardation in $P$. vanammei (Thitamadee et al., 2016) there by affecting the production and profits in commercial shrimp farming. The recommended management measure for $E$. 
hepatopenaei is to treat the water with calcium hypochlorite at a rate of $18 \mathrm{mg} / \mathrm{l}$; treating the hatchery facilities using $2.5 \%$ sodium hydroxide solution with a contact time of three hours and rinsing using acidified chlorine; inactivation of EHP spores in shrimp ponds can be done by using quick lime at a rate of 6 tons/hectare and maintain the moist soil at a $\mathrm{pH}$ level of 12 for few days (Limsuwan et al., 2008; Sritunyalucksana et al., 2014). The prevalence of hepatopancreatic microsporidiosis can be a serious issue in $P$. vanammei culture as it can cause severe growth retardation and play a major role in white fecal syndrome. Hence, the shrimp farmers undertaking $P$. vanamme $i$ farming operations should take necessary precautionary measures to avoid this devastating parasite causing retarded growth and associated production and economic loss.

\section{References}

Anderson, I. G., Shariff, M., Nash, G. 1989. A hepatopancreatic microsporidian in pond-reared tiger shrimp, Penaeus monodon, from Malaysia. Journal of Invertebrate Pathology, 53(2), 278280.

Biju, N., Sathiyaraj, G., Raj, M., Shanmugam, V., Baskaran, B., Govindan, U., Yohannan, R. 2016. High prevalence of Enterocytozoon hepatopenaei in shrimps Penaeus monodon and LitoPenaeus vannamei sampled from slow growth ponds in India. Diseases of Aquatic Organisms, 120, 225-230.

Chayaburakul, K., Nash, G., Pratanpipat, P., Sriurairatana, S., Withyachumnarnkul, B. 2004. Multiple pathogens found in growth-retarded black tiger shrimp Penaeus monodon cultivated in Thailand. Diseases of Aquatic Organisms, 60(2), 89-96.

Ha, N.T., Ha D.T., Thuy N.T., Lien, V.T.K., 2010. Enterocytozoon hepatopenaei parasitizing on tiger shrimp (Penaeus monodon) infected by white feces culture in Vietnam has been detected (In Vietnamese with English abstract). Agriculture and rural development: science and technology (translation from Vietnamese), 12, 45-50.

Hudson, D.A., Hudson, N.B., Pyecroft, S.B., 2001. Mortalities of Penaeus japonicus prawns associated with microsporidian infection. Australian Veterinary Journal 79, 504-505.

Jaroenlak, P., Sanguanrut, P., Williams, B. A. P., Stentiford, G. D., Flegel, T. W., Sritunyalucksana, K., Itsathitphaisarn, O. 2016. A nested PCR assay to avoid false positive detection of the microsporidian Enterocytozoon hepatopenaei (EHP) in environmental samples in shrimp farms. PLoS ONE 11(11): e0166320.

Limsuwan, C., Chuchird, N., Laisutisan, K. 2008. Efficacy of calcium hypochlorite on the prevalence of microsporidiosis (Thelohania) in pond-reared Litopenaeus vannamei. Kasetsart Journal: Natural Science, 42(2), 282-288.

Liu, Z., Zhang, Q.-L., Wan, X.-Y., Huang, J., 2015. Development of real-time PCR assay for detection of microsporidian Enterocytozoon hepatopenaei and detection in shrimp samples under different growth rates. Progress in Fishery Science (in press, in Chinese, English Abstract).

MPEDA, 2015. MPEDA press release export statistics 2014-15 and RGCA, http://mpeda.gov.in.

Rajendran, K. V., Shivam, S., Ezhil Praveena, P., Joseph Sahaya Rajan, J., Sathish Kumar, T., Avunje, S., Vijayan, K. K. 2016. Emergence of Enterocytozoon hepatopenaei (EHP) in farmed Penaeus (Litopenaeus) vannamei in India. Aquaculture, 454, 272-280. 
Sritunyalucksana, K., Sanguanrut, P., Salachan, P. V., Thitamadee, S., Flegel, T. W. 2015. Urgent appeal to control spread of the shrimp microsporidian parasite Enterocytozoon hepatopenaei (EHP). Network of Aquaculture Centres in Asia-Pacific (NACA), 4-6.

Sriurairatana, S., Boonyawiwat, V., Gangnonngiw, W., Laosutthipong, C. 2014. White feces syndrome of shrimp arises from transformation, sloughing and aggregation of hepatopancreatic microvilli into vermiform bodies superficially resembling gregarines. PLoS ONE 9(6): e99170

Suebsing, R., Prombun, P., Srisala, J., Kiatpathomchai, W. 2013. Loopmediated isothermal amplification combined with colorimetric nanogold for detection of the microsporidian Enterocytozoon hepatopenaei in penaeid shrimp. Journal of Applied Microbiology, 114, 1254-1263.

Tang, K. F. J., Pantoja, C. R., Redman, R. M., Han, J. E., Tran, L. H., Lightner, D. V. 2015. Development of in situ hybridization and PCR assays for the detection of Enterocytozoon hepatopenaei (EHP), a microsporidian parasite infecting penaeid shrimp. Journal of Invertebrate Pathology, 130, 37-41.

Tangprasittipap, A., Srisala, J., Chouwdee, S., Somboon, M., Chuchird, N., Limsuwan, C., Sritunyalucksana, K. (2013). The microsporidian Enterocytozoon hepatopenaei is not the cause of white feces syndrome in whiteleg shrimp Penaeus (Litopenaeus) vannamei. BMC Veterinary Research, 9(1), 139.

Thitamadee, S., Prachumwat, A., Srisala, J., Jaroenlak, P., Salachan, P. V., Sritunyalucksana, K., Itsathitphaisarn, O. 2016. Review of current disease threats for cultivated penaeid shrimp in Asia. Aquaculture, 452, 69-87.

Tourtip, S., Wongtripop, S., Stentiford, G. D., Bateman, K. S., Sriurairatana, S., Chavadej, J., Withyachumnarnkul, B. 2009. Enterocytozoon hepatopenaei sp. nov. (Microsporida: Enterocytozoonidae), a parasite of the black tiger shrimp Penaeus monodon (Decapoda: Penaeidae): Fine structure and phylogenetic relationships. Journal of invertebrate pathology, 102(1), 21-29.

\section{How to cite this article:}

Giridharan, M. and Uma, A. 2017. A Report on the Hepatopancreatic Microsporidiosis Caused by Enterocytozoon hepatopenaei (EHP) in Penaeus vannamei (Pacific White Shrimp) Farms in Thiruvallur District, Tamilnadu, India. Int.J.Curr.Microbiol.App.Sci. 6(6): 147-152. doi: https://doi.org/10.20546/ijcmas.2017.606.017 